\title{
EFFECTIVENESS OF STRUCTURED TEACHING PROGRAMME ON KNOWLEDGE OF BLOOD DONATION AMONG GOVERNMENT HIGHER SECONDARY SCHOOL STUDENTS \\ *Mr. B. Pandiyan
}

\begin{abstract}
Blood can save millions of life, and Young people are the hope and future of a safe blood supply in the world. India needs about 6 to 7.5 million units of blood annually and every year there will be a gradual increase in this demand. National blood donation policy of India highlights on the need of supplying safe and quality blood to the need through collecting blood from regular voluntary blood donor. To assess the pretest and post test score regarding knowledge on blood donation, to evaluate the effectiveness on knowledge of blood donation among higher secondary students, to find out the association between the posttest knowledge score with selected demographic variables. The investigator used quasi-experimental research design for one group pre test\& posttest. Simple Random Sampling Technique was used. Sample size 100 school students. The investigator used planned structured teaching programme to assess the knowledge of blood donation among school students. The conceptual framework selected for the this study was based on modified General System Model - Ludwig Von Bertalanffy (2011).The data was analyzed by using descriptive and inferential statistics, paired $\mathrm{t}^{\mathrm{t}}$ test used for structured teaching programme. In this group of students pretest known mean score 12.31 and SD 2.452 and posttest mean score was 22.84SD 2.272 and $\mathrm{t}^{6}$ test value 29.11 at the significant level of $\mathrm{P}<0.05$ tabulated value 1.98. so hypothesis was accepted and STP effective.
\end{abstract}

Key Words: Structured Teaching Programme, Blood Donation, Knowledge, Voluntary Blood Donors, School Students.

\section{INTRODUCTION:}

\section{-Donateblood andsave}

life"

A blood donation means when a healthy person voluntarily has blood drawn and used for transfusions. Blood donation is an integral and essential part of our healthcare system. Without blood donations, many of the medical procedures that we take for granted could not take place ${ }^{1}$. According to $\mathrm{WHO}$, an estimated $38 \%$ of reported voluntary blood donations are contributed by people under the age of 25 . WHO also insist countries to focus on young people to achieve 100 percent voluntary unpaid blood donation. Young students arehealthy, active, dynamic receptive and constitute a greater proportion of population. They have to be encouraged, inspired and motivated to donate blood voluntarily. ${ }^{2}$

Blood can save millions of life, and Young people are the hope and future of a safe blood supply in the world. India needs about 6 to 7.5 million units of blood annually and every year there will be a gradual increase in this demand. National blood donation policy of India highlights on the need of supplying safe and quality blood to the need through collecting blood from regular voluntary blooddonors ${ }^{1}$. 


\section{STATEMENT OF THE PROBLEM:}

-Effectiveness of structured teaching programme on knowledge of blood donation among students in Government Higher Secondary School at Sothupakkam, Kanchipuram Districtll.

\section{OBJECTIVES}

1. To assess the knowledge of blood donation among Higher Secondarystudents.

2. To evaluate the effectiveness of STP on knowledge of blood donation among Higher SecondaryStudents.

3. To find out the association between knowledge with selected demographic variables

\section{METHODOLOGY:}

Quasi-experimental design was used for the study. The study was conducted at Government Higher Secondary School Sothupakkam, Kanchipuram District. Eleventh Standard Students in Goverment Higher secondary school at sothupakkam, Kanchipuramdistrict.

100 Government Higher Secondary school students in Sothupakkam have been selected as samples for this study. Simple Random Sampling Technique by using the lottery method.

\section{CRITERIA FOR SELECTION OF SAMPLE \\ Inclusion criteria}

1. Eleventh standardstudents

2. Students who are willing to participate in the study

3. Students who know English ortamil

4. Students who are present at the time of datacollection

\section{Exclusion criteria}

1.The students who do not have involvement in thestudy.

2. Students with long absentism in theclass.

3. The students who are sick in the class.

The conceptual framework selected for the this study was based on modified General System Model - Ludwig Von Bertalanffy the study was conducted in Government Higher Secondary School at sothupakkam, Kancheepuram district. The data obtained was analyzed by using descriptive and inferential statistical tests.

\section{MAJOR FINDINDS:}

\begin{tabular}{|c|c|c|c|}
\hline $\begin{array}{l}\text { Knowledge } \\
\text { scores }\end{array}$ & Mean & $\begin{array}{l}\text { Standard } \\
\text { deviation }\end{array}$ & p-value \\
\hline Pretest & 12.31 & 2.452 & \multirow{3}{*}{$\begin{array}{l}\mathrm{P}<0.05 \\
\text { tabulated } \\
\text { value1.98 } \\
\mathrm{f}^{\mathrm{t}} \quad \text { test } \\
\text { value } \\
29.11\end{array}$} \\
\hline Posttest & 22.84 & 2.272 & \\
\hline $\begin{array}{l}\text { Improvement } \\
\text { score }\end{array}$ & 10.53 & 3.61 & \\
\hline
\end{tabular}

In overall pretest mean score was 12.31 with the standard deviation of 2.452 . The posttest knowledge of mean score was 22.84 with standard deviation of 2.272. The improvement score of mean value was 10.53 with the standard deviation of 3.61 and the ttest value was 29.11 , which was statistically significant at $\mathrm{p}<0.05$ level

\section{RECOMMENDATIONS}

Based on the research findings the following recommendations can be made:

The same study can be replicated on a larger sample and also at differentsettings. 
A comparative study can be done between semi-rural and semi urban schoolstudents.

> A descriptive study can be conducted on assessment of knowledge regarding blood donation.

A structured teaching programme on blood donation can be prepared and given to the teachers and the parent's .so that they can impart knowledge to all schoolstudents.

\section{References:}

1. www.WHO.com

2. Basavanthappa B.T Text book of Research for Nursing, $2^{\text {nd }}$ edition,jaypee.

3. Kothari C.K Research Methodology methods and techniques, $2^{\text {nd }}$ edition, viswaprakasam,philadelphia.1996.

4. Polit.D.F, Hungler B.P, Nursing Research principles and methods\| 3rd edition, Lippincott,USA.1978. 